\title{
Evaluation of the Clinton River Watershed Water Quality as an Indication of Salinization due to Road Deicing Methods
}

\author{
Lucas Pascotto ${ }^{1}$
}

${ }^{1}$ Athens High School, Troy, MI, USA

\section{ABSTRACT}

The purpose of this study was to determine the full effect that road salting practices in Southeastern Michigan have had on local streams. The research method followed as an experimental procedure commonly used in the environmental science field. Variables measured include $\mathrm{pH}$, total phosphates, nitrates, turbidity, salt content and conductivity. The resulting conclusions indicate a significant change in water quality between the non-winter and winter months tested. Although significant change was identified, no single value exceeded legal limits in the respective area.

\section{Introduction}

Environmental salinization is a naturally occurring process that affects both soil and water. It is defined as the process by which water-soluble salts reach and infiltrate the surface of an environment ${ }^{10}$. In nature, it is caused by increased dissolved salt contents of the water supply; however, it is also further accelerated by human salt usage. Salinization can be dangerous to any living organism that coexists with the affected environment, including humans. Increased salt content in an ecosystem can affect most, if not all, levels of an ecological hierarchy. By increasing dryness in affected soil, salinization can make previously fertile land too poor to produce anything ${ }^{6}$. It can also disrupt other naturally occurring processes and risk species extinction. When saline water travels to roadways, it can corrode much of the infrastructure it comes in contact with. This includes roads, bridged overpasses, and vehicles, amounting in a considerable economic detriment. Simply put, environment salinization is a destructive occurrence, and this paper explores its prevalence in the Clinton River Watershed, due to increased road salt usage.

\section{Road-salting Necessity}

Michigan is known to be one of the coldest states of the U.S., and its humid continental climate leaves it subject to long winters. Surrounded by the Great Lakes, Michigan's snowy road conditions can persist from October through April, striking the state with seven months of road salting. Most commonly, $\mathrm{NaCl}$ is used for road de-icing ${ }^{1}$. This common rock salt, however, is not purified, containing heavy metal contaminants such as lead, iron, aluminum, and phosphorus as it is delivered to roads. Fueled by increasing public demand, Michigan skyrocketed its use of road salt in the last 30 years ${ }^{9}$. Michigan Public agencies report using 2 million tons of salt annually to clear up snow and ice ${ }^{3}$. The economic specifics of this finding are not of particular interest to this study; however, it does remain essential to understanding state decision-making. 


\section{Infiltration of Water Systems}

Still, sodium chloride remains the most affordable and widely used road salt. In its purest form, $\mathrm{NaCl}$ is composed of two ions: sodium, and chloride. As a water-soluble salt, in the presence of water, two chemically bonded ions split up into $\mathrm{Na}+$ and $\mathrm{Cl}$ - These ions, when split, become extremely corrosive to automobiles and infrastructure in contact ${ }^{24}$. Both water and salt can be corrosive to cars; however, when combined, they can have a destructive force ${ }^{3}$. As the ice melts, the liquid water mixes and dissolves the salt, picking up the released ions and the aforementioned contaminants with it. This salty mixture is known as brine. The brine is then drained through sewage, roadside runoff, and groundwater infiltration, increasing salt contents of both the soil and water of surrounding areas ${ }^{2}$. Chlorine is a dangerous element when present in water as a soluble substance. Its unstable nature allows for many compounds to be formed, posing a threat to organisms utilizing that water. $\mathrm{HCl}$, Hydrochloric acid, is a simple compound that takes little agitation to form. As a strong acid, its prevalence in water can be extremely toxic and shift $\mathrm{pH}$ dramatically ${ }^{5}$. Similarly, chloride can also bond with more complex chemicals and form chloroform, $\mathrm{CHCl}_{3}$, a substance that disables the human central nervous system and can have harmful repercussions on the liver and kidneys.

\section{Topography Interaction}

External factors can further stimulate the movement of salt. Any process that affects the soil-water balance may affect accumulation of salts in the soil deposited by brine. These processes include irrigation, drainage, rooting characteristics, and farming practices ${ }^{22}$. Among these, rooting characteristics are especially significant. Roadside topography typically consists of vegetation with exposed and weak rooting. "In humid climates, salinization occurs on rims of depressions, edges of drainageways, hillslopes, and low-lying areas surrounding shallow bodies of water ${ }^{14}$." Michigan topography is consistent with this description and is primarily made up of rivers, streams, and lakes, all low-lying areas subject to salinization in humid climates.

\section{Water Quality Measurement}

Water quality in southeastern Michigan presents itself as a big concern. Public beaches are often closed due to unacceptably high E. coli levels; necessity for stream water management is at an all-time high. Moreover, the atrocities of the Flint Water Crisis are indicative of the lack of governmental concern towards water quality. On a national level, the EPA offers a Water Quality Standards Index (WQSI), an index of provisionary values authorized by federal law. This index, however, only represents monitoring for bodies of water used for recreation (e.g., swimming and boating), scenic enjoyment, and fishing ${ }^{14}$. The WQSI includes a wide range of purposes for bodies of water, leaving a large gap for human risk. The last national stream water quality assessment guided by WQSI is dated to 2004 and included 1,392 sites from which only 73 were from Michigan. Alternatively, on a state level, the Michigan government introduced "Michigan Clean Water Corps" (MiCorps) through Michigan Executive Order in conjunction with the Department of Environment, Great Lakes, and Energy (EGLE) in $2003^{14}$. This initiative provides extensive data aligned to quality standards specific to potable water: water to be packaged for consumption. Since its genesis, the database has gathered over 17 years of data; unfortunately, none of it assesses the development of a stream's water quality. Plentiful research has been conducted tracing water quality of streams on a national level. However, the Clinton River Watershed remains seldom researched. The primary objective of this study is to answer the research question: How does environment salinization caused by road salt usage contribute to stream water quality in the Clinton River Watershed? 


\title{
Review of Literature
}

\author{
Impact on Vegetation
}

Salinization is one of the most common potential environmental disturbances in a given environment. Increased salt content in soil is highly disruptive to plant growth. University of Oklahoma graduate Pooja Shrivastava, Ph.D. and colleague Rajesh Kumar conducted a study that analyzed crop yield as salinity increased. The study concluded that essential crops such as Triticum-aestivum (wheat) and Oryza-sativa L. (rice) had severely harmed growth. They quote, "average yields are only a fraction - somewhere between $20 \%$ and $50 \%$ of recorded yields ${ }^{19}$." Michigan, in particular, is a significant producer of wheat and hay, two crops which showed to respond tremendously to changes in soil salinity. "This occurs because salinity affects almost all aspects of plant development," they elaborated, “...including vegetative growth, ion toxicity, osmotic stress, nutrient deficiency, and limited uptake of water from soil ${ }^{19}$." To show the true impact of salinization, a peer-reviewed meta-analysis study traced the spread of elevated heavy metal content through broad spatial scales and synoptic snapshots. A synoptic snapshot is a collage of data points from separate locations compiled into one image. The spatial spread of contaminants can be easily read through these snapshots. The study tracked Aluminum, Copper, Lead, Zinc, Sodium, and Chloride. Through an analysis of 70 sites, researchers found $\mathrm{Na}+$ to spread at a rate of $13.1(\mu \mathrm{g} / \mathrm{L})$ and $\mathrm{Cl}-$ at $23.7(\mu \mathrm{g} / \mathrm{L})^{21}$. Although this may seem insignificant, results from non-winter months were $3.2(\mu \mathrm{g} / \mathrm{L})$ and $5.4(\mu \mathrm{g} / \mathrm{L})$, respectively ${ }^{21}$. This finding insinuates that during the winter, there is not only a substantial increase in ion content but also at the rate they spread. As temperatures drop, a permafrost layer is created, freezing the saline water and its contents in the sub-soil. Subsequently, when the layer thaws in springtime and crop farmers are ready to utilize the most fertile months of the year, they find their crop growth severely hindered as the saline solution remains in the soil.

\section{Salinization's Threat to Ecosystems}

Salinization can also have adverse effects on the ecological basis of a water system. The biological diversity of natural streams is expansive, and one small change could cause plenty to go wrong. As shown by a peer-reviewed study conducted by WT Pecher, microbial ecologist and parasitology expert, “...seasonal exposure to road salt leads to an increased presence of halophilic microorganisms, even months after road salt exposure ${ }^{16}$." Pecher and his team developed a semi-quantitative procedure utilizing halophilic microbes, bacteria that thrive in high salt concentrations, as biomarkers to evaluate ongoing salt pollution. Once these microorganisms reach freshwater, they suddenly release all salt content from their bodies and replace it with freshwater in a process called osmotic shock. This, in turn, results in the salt content of water to spike. For aquatic life relying on freshwater, this process can be life-threatening. Furthermore, a review of the effect of chemicals on aquatic life by Christine Fazio, environmental law professor at Fordham University, explains that exposure to high levels of chloride in water, especially for an extended term, affects abundance and reproduction of aquatic organisms ${ }^{6}$. Fazio paired increased chloride level reports to a biological survey of fish at various bodies of water. During her study, she noted that fish produced notably less eggs during their most reproductive months in areas with elevated chloride content. Saltwater is also denser than freshwater, causing it to sink and accumulate at lake and stream floors ${ }^{6}$. In freezing temperatures, the surface freezes over, leaving fish confined to the salty mixture for months at a time. Many fish populations, as explained by researcher William Wurts Ph.D. in Wildlife and Fisheries Sciences, do not have necessary adaptations to survive for long in a saline environment causing their population, and potentially species, to go extinct. In his study, 15 different species of freshwater fish were constrained to survive in saltwater environments of increasing salinity. As a result, only three species were able to survive through osmosis in the highest tested salinity ${ }^{23}$. When considering the large bodies of water surrounding Michigan, a substantial amount of fish species would be affected. 


\section{Effect of Salinization on Health}

Inconsistent conditions that arise from road salt usage also pose threats to humans. As discussed previously, salts used for road de-icing are not pure. Along with heavy metals, salts can also bring cyanides into the water, namely ferrocyanide. Ferrocyanide is a compound added to road salt mixtures to prevent clumping of big salt deposits. Kristen Exall, water quality researcher for the Journal of Canada and two other colleagues, conducted an observational study in which measurements of ferrocyanide in urban snowmelt and runoff were analyzed. The team gathered data from 193 sites and found that $21 \%$ of the sites contained cyanide levels above legal limits ${ }^{5}$. Cyanide is listed as a secondary standard under Federal Safe Drinking Water Acts meaning that if trace amounts are detected in water samples, the water becomes subject to further testing by the EPA. In correlation with this study, effects on humans were revealed by Steven Corsi, hydrologist researcher, and his team at Midwest Water Science Center. In the study, historical data provided by the U.S. Geological Survey was examined for 17 metropolitan areas. Chloride concentrations were found to exceed EPA water quality criteria at $55 \%$ of the 168 surveyed monitoring locations during winter months (November-April). By contrast, from May to October, only 16\% of the sites exceeded EPA regulation. Thus, the increased $39 \%$ can be reasonably attributed to road salt usage. The study released findings that quoted: "Bioassay results from runoff events confirm that observed high concentrations of ferrocyanide caused acute and chronic toxicity to individuals ${ }^{4}$." The Detroit River is used for potable water, meaning that any contaminants not commonly found in water will not filter out in the cleansing process. This occurs as water filtration technology has not yet advanced to filter out custom compounds as they are detected on a necessity basis. The Michigan Department of toxicology warns of the consumption of ferrocyanide as causing severe irritation to the stomach, trachea, and nausea ${ }^{15}$. This study, specifically, will analyze the Gibson Creek, a tributary of the Detroit River. The Gibson Creek-located in Oakland County, Michigan-is a part of the Clinton River Watershed, a collection of water systems that empty into the Detroit River. Though one small creek will not have enough ferrocyanide to affect a whole population, the Gibson Creek is not the only tributary of the Detroit River that is affected by road salt. If every stream or creek that feeds into the Detroit River carries trace amounts of ferrocyanide, there will be enough to cause noticeable concern. The findings of this study may assist future development of water filtration strategies as contaminants found in a common stream such as the Gibson Creek are likely found elsewhere.

\section{Driving Safety Jeopardization}

Along with added human health risks, road salt usage also poses driving hazards. When salt leaks into nearby streams, making them more saline, it attracts sodium-deficient mammals such as moose and deer to roadways. The increased animal crossings, coupled with worsening winter driving conditions, leads fatal road accidents to increase in occurrence. A published study conducted by Dr. Gopalakrishnan at SRM Medical Hospital and Research Center, takes a public health perspective on road accidents. Through the methodology of comparing public government data, the study concluded that, compared to summer months, accidents during the winter rose by almost 56\% in small suburban cities. Furthermore, accidents were more likely to be fatal and destructive ${ }^{8}$. According to Michigan Government Traffic Crash Statistics (MGTCS), Oakland County is the highest county in Michigan with deer-related crashes. Out of 70,338 crashes in 2018, 1,851 were deer related. For simplicity, 1 in every 38 crashes involves deer ${ }^{15}$. Moreover, $48 \%$ of these crashes occurred between October and December.

\section{Methods}

This research study relies heavily on scientific data analysis; thus, an experimental method of inquiry was followed. Data gathered was done so by the student researcher, rendering it primary. While most data were quantitative, this study also relies on qualitative analysis of each parameter and its meaning. In the interest of acquiring all necessary 
materials for this experiment, an order was placed with a chemical supply company, Carolina Investigations. Table 1.1 is included for assistance in experiment replication and enlists all products and expenses.

\section{Material Specification}

Materials such as beakers, graduated cylinders, thermometers, hot plates, balances, $\mathrm{pH}$ strips, distilled water, and a spectrophotometry machine were already made available to the study without the need to order them. Such materials are included in the table for facilitation in recreation and thoroughness of the experiment.

For sample collection, six glass jars were used. The effectiveness of the glass at maintaining accurately representative data is crucial to this experiment. The glass' amorphous composition prevents any particles from entering and exiting the enclosed environment, subsequently protecting it from affecting the data and results. An alternative to glass is polypropylene plastic; however, it can only be used for short-term storage before Bisphenol A, a harmful chemical, begins to leech into the water and disrupt data. Each jar was sealed with an air-tight, lab grade lid until data collection. Three test sites along the Gibson Creek were selected on a topographic basis.

Table 1.1. Itemized Material List

\begin{tabular}{|l|l|l|l|}
\hline $\begin{array}{c}\text { Item/Order } \\
\text { Number }\end{array}$ & \multicolumn{1}{|c|}{ Product Name } & \multicolumn{1}{c|}{ Amount } & \multicolumn{1}{c|}{ Cost } \\
\hline$\# 721230$ & Carolina ${ }^{\circledR}$ Beaker Variety Pack & 1 case & $\$ 27.95$ \\
\hline$\# 974065$ & Immersion Thermometer & 1 unit & $\$ 5.95$ \\
\hline$\# 652790$ & LaMotte® Nitrate Nitrogen Test Kit & 1 kit & $\$ 66.35$ \\
\hline$\# 894726$ & Hydrion® Spectral pH Strips (pH 0.0 to 14.0) & 1 pack & $\$ 12.40$ \\
\hline$\# 715613$ & Cylindric 8oz glass jars & 6 jars & $\$ 5.00$ each \\
\hline$\# 653303$ & Carolina® Digital Spectrophotometer & 1 machine & $\$ 1,235.00$ \\
\hline$\# 652920$ & LaMotte ${ }^{\circledR}$ Total Phosphate Water Test Kit & 1 kit & $\$ 96.35$ \\
\hline$\# 701012$ & Carolina Hot Plate & 1 machine & $\$ 270.00$ \\
\hline$\# 840688$ & Conductivity Indicator & 1 unit & $\$ 34.50$ \\
\hline$\# 961865$ & Graduated Cylinder Set & 1 set & $\$ 37.55$ \\
\hline
\end{tabular}

\section{Site Selection}

The first site, site A, was selected for its distance from any roads. The site is located inside a city of Troy recreational park, as the creek runs through it. This site is the furthest upstream in relation to the other sites selected, therefore its labeling as site "A". By contrast, site B, the second site, was chosen for its proximity to roads. A major road overpass bridge was built just above the creek. The proximity of this site to the roads allow for an analytical view of how impactful the brine may be. As the salt from roads melts, forming a brine, it is carried down directly into the creek under the overpass. Site B is situated downstream from site A. The distance between sites A and B was found to be roughly $2100 \mathrm{ft}$. Just as sites A and B are $2100 \mathrm{ft}$ apart, sites B and C are also $2100 \mathrm{ft}$ in distance. Site C was chosen for its equidistance to other sites. As the furthest downstream site, the position of this site allows for a complete analysis of each parameter as the stream moves downward. The respective contents can be compared as the creek moves further down-stream to reveal the effect of proximity to roads on affected parameters, as well as how well each contaminant is retained by the water. Thus, a complete understanding of the impact of road salt can be made from these three sites. 


\section{Procedural Element}

Once at each site, the glass container to be used was rinsed with stream water. The purpose of this is to eliminate any preexisting externalities in the glass. The glass jar was then carefully submerged 5 inches underwater, to not disturb any soil movement. Once each jar was full of water, the lids were placed. Each sample was stored at room temperature and atmospheric pressure until the time of data collection. The parameters analyzed in each sample include $\mathrm{pH}$, total phosphates, nitrates, turbidity, salt content, and conductivity. In order to establish a clear distinction of the role that road salt plays in water quality, two sampling events took place. The first event occurred on October $4^{\text {th }}, 2019$, weeks before the first road salting event in the city of Troy, to serve as a control and establish a basis for analysis. The second collection took place on Feb $20^{\text {th }}$, 2020, one day after a major road salting event. The three sites were kept the same across both sampling events. Multiple sites provide a basis for a prediction to be drawn in regard to the effect of the salt contamination on the Detroit River.

\section{Parameter Testing}

The six parameters were measured using test and data collection methods that are regularly used in the environmental science field of study and body of knowledge. These procedures are delineated by the EPA and can be further investigated in Appendix A.

The last test was used to find the salt content of each collected site. The EPA does not have a specific method of analysis for this test, thus the following procedure was developed by the student researcher. Just as salt lowers the freezing point of water, it also raises the boiling point of water. Pure water boils at $100^{\circ} \mathrm{C}$; in theory, when salt is added, it will boil at a higher temperature. For each sample, $200 \mathrm{~mL}$ of water was poured into a beaker. The beaker was then placed on a hot plate and brought to a boil. The boiling temperature of each sample was recorded. Through simple algebraic manipulation of the Van't Hoff equation, the salt content of the samples can be found. The equation, $\Delta \mathrm{T}_{\mathrm{b}}=\left(\mathrm{K}_{\mathrm{b}}\right) \mathrm{x}(\mathrm{m}) \mathrm{x}(\mathrm{i})$, was used where " $\mathrm{K}_{\mathrm{b}}$ " is the molal boiling point constant, " $\mathrm{m}$ " is the molality of the solution, and " $\mathrm{i}$ " is the Van't Hoff factor. After each value was substituted in, the final salt content was recorded in $\mathrm{g} / \mathrm{L}$.

All six parameters were measured for each sample and values recorded in the data tables below. After the raw data was recorded, it was converted to a Q-value using curve graphs provided by the EPA. This Q-value reflects the overall quality of each respective parameter compared to distilled water. Pure water consists of a Q-value of 100 for each value, therefore, the lower the value is, the more the sample deviates from pure water. Some variance is to be expected as the stream naturally has contaminants, however, excessively low values will indicate lower water quality. This Q-value was then multiplied by the weighing factor of each parameter on water quality. A total value was found, and the sum of all parameters represented the final water quality for each sample.

Table 1.2 Ranges listed in the table below are from the 100-point index, each providing general terms for water quality

\begin{tabular}{|l|l|}
\hline \multicolumn{2}{|c|}{ Water Quality Index Ranges } \\
\hline $90-100$ & Excellent \\
\hline $70-90$ & Good \\
\hline $50-70$ & Fair \\
\hline $25-50$ & Poor \\
\hline $0-25$ & Very Poor \\
\hline
\end{tabular}




\section{Results}

Table 2.1. October $4^{\text {th }}-$ Site A

\begin{tabular}{|l|l|l|l|l|}
\hline \multicolumn{1}{|c|}{ Test } & \multicolumn{1}{|c|}{ Raw Data } & \multicolumn{1}{c|}{ Q-Value } & Weighing Factor & \multicolumn{1}{c|}{ Total } \\
\hline 1.pH & 7.49 & 82 & 0.17 & 13.94 \\
\hline 2.Total Phosphate & $0.32 \mathrm{mg} / \mathrm{L}$ & 74 & 0.12 & 8.88 \\
\hline 3.Nitrates & $1.5 \mathrm{ppm}$ & 74 & 0.20 & 14.80 \\
\hline $\begin{array}{l}\text { 4.Turbidity } \\
\text { 5.NaCl (Salt con- } \\
\text { tent) }\end{array}$ & $25 \mathrm{JTU}$ & 86 & 0.16 & 13.76 \\
\hline $\begin{array}{l}\text { 6.Conductivity } \\
\text { O. }\end{array}$ & $108 \mu \mathrm{g} / \mathrm{cm}$ & 76 & 0.15 & 12.60 \\
\hline
\end{tabular}

Overall water Quality: 79.18-Good

Table 2.2. February $20^{\text {th }}-$ Site A

\begin{tabular}{|l|l|l|l|l|}
\hline \multicolumn{1}{|c|}{ Test } & \multicolumn{1}{|c|}{ Raw Data } & \multicolumn{1}{c|}{ Q-Value } & Weighing Factor & \multicolumn{1}{c|}{ Total } \\
\hline $1 . \mathrm{pH}$ & 8.74 & 72 & 0.17 & 12.24 \\
\hline 2.Total Phosphate & $0.40 \mathrm{mg} / \mathrm{L}$ & 67 & 0.12 & 8.04 \\
\hline 3.Nitrates & $3.6 \mathrm{ppm}$ & 57 & 0.20 & 11.40 \\
\hline $\begin{array}{l}\text { 4.Turbidity } \\
\text { 5.NaCl (Salt con- } \\
\text { tent) }\end{array}$ & $65 \mathrm{JTU}$ & 68 & 0.16 & 10.88 \\
\hline 6.Conductivity & $146 \mu \mathrm{S} / \mathrm{cm}$ & 59 & 0.15 & 8.85 \\
\hline
\end{tabular}

Overall Water Quality: 64.01-Fair 
Table 2.3. October $4^{\text {th }}-$ Site B

\begin{tabular}{|l|l|l|l|l|}
\hline \multicolumn{1}{|c|}{ Test } & \multicolumn{1}{|c|}{ Raw Data } & \multicolumn{1}{c|}{ Q-Value } & Weighing Factor & \multicolumn{1}{c|}{ Total } \\
\hline 1.pH & 7.07 & 78 & 0.17 & 13.26 \\
\hline 2.Total Phosphate & $0.22 \mathrm{mg} / \mathrm{L}$ & 80 & 0.12 & 9.60 \\
\hline 3.Nitrates & $1.5 \mathrm{ppm}$ & 74 & 0.20 & 14.80 \\
\hline $\begin{array}{l}\text { 4.Turbidity } \\
\text { 5.NaCl (Salt con- } \\
\text { tent) }\end{array}$ & $35.52 \mathrm{~g} / \mathrm{L}$ & 78 & 0.16 & 12.48 \\
\hline & 68 & 0.15 & 10.20 \\
\hline 6.Conductivity & $122 \mu \mathrm{S} / \mathrm{cm} 1$ & 73 & 0.20 & 14.60 \\
\hline
\end{tabular}

Overall Water Quality: 74.94-Good

Table 2.4. February $20^{\text {th }}-$ Site B

\begin{tabular}{|l|l|l|l|l|}
\hline \multicolumn{1}{|c|}{ Test } & \multicolumn{1}{|c|}{ Raw Data } & \multicolumn{1}{c|}{ Q-Value } & Weighing Factor & \multicolumn{1}{c|}{ Total } \\
\hline 1.pH & 8.32 & 65 & 0.17 & 11.05 \\
\hline 2.Total Phosphate & $0.38 \mathrm{mg} / \mathrm{L}$ & 68 & 0.12 & 8.16 \\
\hline 3.Nitrates & $3.7 \mathrm{ppm}$ & 56 & 0.20 & 11.20 \\
\hline $\begin{array}{l}\text { 4.Turbidity } \\
\text { 5.NaCl (Salt con- } \\
\text { tent) }\end{array}$ & $8.42 \mathrm{~g} / \mathrm{L}$ & 63 & 0.16 & 10.08 \\
\hline $\begin{array}{l}\text { 6.Conductivity } \\
\text { 2.C2 }\end{array}$ & $43 \mathrm{~S} / \mathrm{cm}$ & 52 & 0.15 & 6.45 \\
\hline
\end{tabular}

Overall Water Quality: 57.34- Fair 
Table 2.5. October $4^{\text {th }}-$ Site C

\begin{tabular}{|l|l|l|l|l|}
\hline \multicolumn{1}{|c|}{ Test } & \multicolumn{1}{|c|}{ Raw Data } & \multicolumn{1}{c|}{ Q-Value } & Weighing Factor & \multicolumn{1}{c|}{ Total } \\
\hline 1.pH & 7.08 & 78 & 0.17 & 13.26 \\
\hline 2.Total Phosphate & $0.27 \mathrm{mg} / \mathrm{L}$ & 77 & 0.12 & 9.24 \\
\hline 3.Nitrates & $1.0 \mathrm{ppm}$ & 84 & 0.20 & 16.8 \\
\hline $\begin{array}{l}\text { 4.Turbidity } \\
\text { 5.NaCl (Salt con- } \\
\text { tent) }\end{array}$ & $3.03 \mathrm{~g} / \mathrm{L}$ & 86 & 0.16 & 13.76 \\
\hline $\begin{array}{l}\text { 6.Conductivity } \\
\text { (116 } \mathrm{JS} / \mathrm{cm}\end{array}$ & 74 & 0.15 & 11.10 \\
\hline
\end{tabular}

Overall Water Quality: 79.16-Good

Table 2.6. February $20^{\text {th }}-$ Site C

\begin{tabular}{|c|c|c|c|c|}
\hline Test & Raw Data & Q-Value & Weighing Factor & Total \\
\hline 1.pH & 7.86 & 76 & 0.17 & 12.92 \\
\hline 2.Total Phosphate & $0.38 \mathrm{mg} / \mathrm{L}$ & 68 & 0.12 & 8.16 \\
\hline 3.Nitrates & $2.2 \mathrm{ppm}$ & 70 & 0.20 & 14.00 \\
\hline 4.Turbidity & $35 \mathrm{JTU}$ & 78 & 0.16 & 12.48 \\
\hline $\begin{array}{lll}5 . \mathrm{NaCl} & \text { (Salt con- } \\
\text { tent) } & & \\
\end{array}$ & $3.68 \mathrm{~g} / \mathrm{L}$ & 67 & 0.15 & 10.05 \\
\hline 6.Conductivity & $127 \mu \mathrm{S} / \mathrm{cm}$ & 68 & 0.20 & 13.60 \\
\hline
\end{tabular}

Overall Water Quality: 71.21-Good

The studies conducted produced the six tables above. Located at the bottom of each table is the final Water Quality Index (WQI) rating for each respective sample. Sample A acquired a score of 79.18 for the October testing, and a WQI of 64.01 for the February test date. Sample B acquired a score of 74.94 for the October testing, and a WQI of 57.34 for the February test date. Sample C acquired a score of 79.16 for the October testing, and a WQI of 71.21 for the February test date. 


\section{Analysis}

Significance to this study can be drawn not only from a comparison of the sites between dates, but also a comparison between each site, $\mathrm{A}, \mathrm{B}$ and $\mathrm{C}$ on the same date. Row 1 of the tables details the results for $\mathrm{pH}$ tests. $\mathrm{pH}$ is a measure of free-floating ions, $\mathrm{H}^{+}$and $\mathrm{OH}^{-}$in a solvent from 0 to 14 . A measure of 0 indicates an extremely acidic solution, while a measure of 14 is attributed to a basic solution. Water typically measures neutrally at a $\mathrm{pH}$ of 7 . It is expected that with the addition of salt, water would turn more basic. This statement holds true for all sites' $\mathrm{pH}$ values. Their values were significantly higher in all sites tested on February than their October counterparts. Sites A and B particularly, experienced an increase of $1.25 \mathrm{in} \mathrm{pH}$. All values were between the 7.00 and $9.00 \mathrm{pH}$ ranges. The values near 7 , such as sites A, B and C prior to road salting, support life for nearly all organism groups. However, as the values rise closer to 9.00, the water becomes unstable for frogs, perch and trout, but still supports plants and snail-groups.
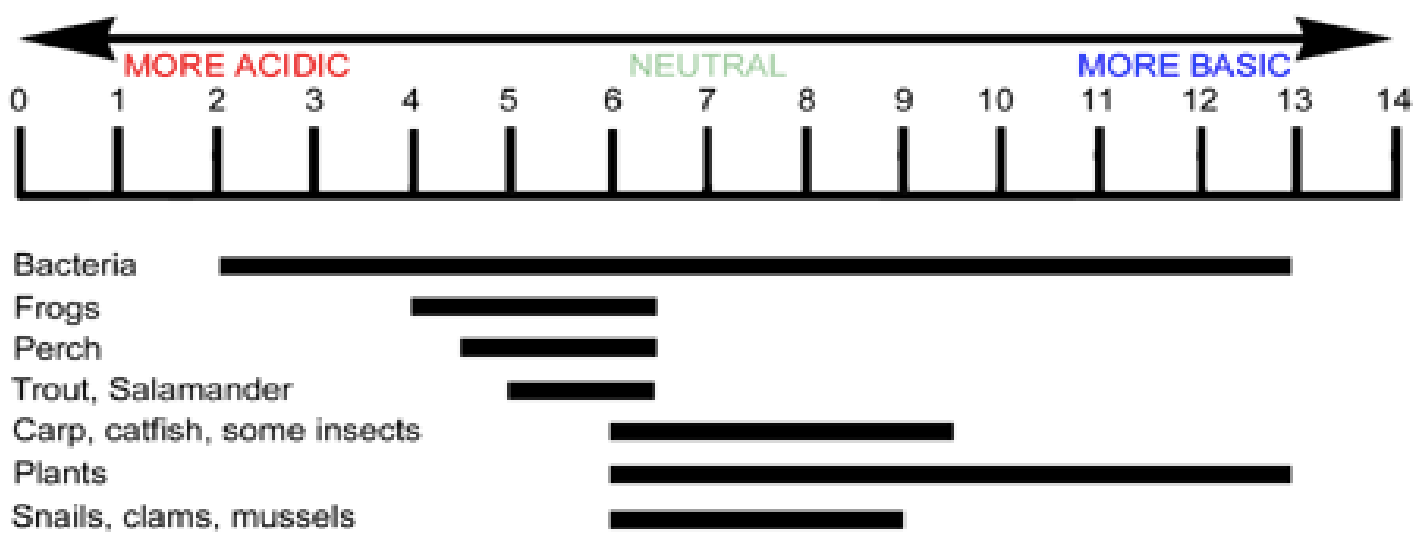

Figure 1. The environmental $\mathrm{pH}$ conditions that each organism typically found in a stream needs to sustain life.

The second row of data shows the values for total phosphate levels in the water. These values only slightly shifted between testing dates. The EPA has set standards that indicate creeks should not exceed $1 \mathrm{mg} / \mathrm{L}$ total phosphorus. Each value measured was well within these limits and hold no cause for alertness. One possible source of elevated total phosphorus is fertilizers. In the snowy season, there is constant runoff as snow melts and leaks into streams. Along with road salt, it also picks up fertilizer particles and delivers them promptly to the watershed, explaining the incremental increase between test dates.

Nitrates showed some statistically significant variances. The largest difference between Oct. and Feb. values occurred in site B, with a difference of 2.2. This difference becomes relevant when considering the sources of nitrates. The toxins released by car discharge cause an increase in nitrates in water. Since site B is located directly under an overpass, it is logical to presume that the increased proximity to automobiles caused the dramatic increase from 1.5 to $3.7 \mathrm{ppm}$.

The fourth-row, turbidity, refers to the number of suspended solids in water. Sites A and C measured a control of 25 JTU in the water. This is an average measurement when considering stream water. Site B had a slightly higher value of $35 \mathrm{JTU}$. This is likely due to the overpass and increased agitation in the water causing solids to move to the surface. The most significant change, however, comes after the road salting occurred. Sites A, B and C experienced an increase of 20,15, $10 \mathrm{JTU}$ respectively. Thus, the further downstream a site is, the more the solids get caught up and settle in the water, lowering the turbidity. It can be deduced that any site tested above A would have an increase of $20 \mathrm{JTU}$ or more. This is likely due to a certain point in the creek that is highly disturbed by freezing temperatures.

The fifth parameter, $\mathrm{NaCl}$, is likely the most accurate at depicting the exact impact of road salt on water quality. Through a simple boiling-elevation method, the exact mass of salt in a specified sample was found. The values were somewhat consistent across all three testing sites prior to road salting, ranging from $2.31 \mathrm{~g} / \mathrm{L}$ to $3.52 \mathrm{~g} / \mathrm{L}$. 
However, after road-salting occurred, values increased dramatically. Site A nearly tripled in salt content reaching $6.73 \mathrm{~g} / \mathrm{L}$. Site B peaked to $8.42 \mathrm{~g} / \mathrm{L}$, the highest recorded value for any sample and date, while site C only experienced an increase of $0.65 \mathrm{~g} / \mathrm{L}$. To put these values in perspective, ocean water typically contains $35 \mathrm{~g} / \mathrm{L}$, thus making $8.42 \mathrm{~g} / \mathrm{L}$ pretty significant considering freshwater would ideally be around $0-1.5 \mathrm{~g} / \mathrm{L}$. From this parameter, it can be seen that road salting did not have a big impact on site $\mathrm{C}$ specifically. With this in mind, when looking at data tables 2.5 and 2.6, minimal differences can be seen within each parameter: Notably, pH only increased by 0.78 , turbidity by $10 \mathrm{JTU}$ and conductivity by $11 \mu \mathrm{S} / \mathrm{cm}$.

The last parameter measured, located on row 6 of tables 2.1-2.6, was conductivity. This is an important parameter to address due to the dissociative properties of salt. When salt enters water, it dissociates into $\mathrm{Na}^{+}$and $\mathrm{Cl}^{-}$. Due to the unstable charges of these ions, the water can be tested using a conductivity probe. Thus, increased conductivity corresponds to increased salt content in the samples. The results from this parameter were consistent with the increase in salt content referred to previously. Site A saw a moderate increase, while site B saw the highest increase in conductivity. Site $\mathrm{C}$ remained relatively unaffected.

Overall Water Quality is the culminating measure of these parameters. It factors in each parameter with their relative impact on water quality. Sites A and $\mathrm{C}$ had nearly the same water quality in the control October sampling, with 79.18 and 79.16 respectively. This is an extremely high rating that ranks as "good" in the index. Between dates, site A dropped approximately 15 values in its rating, from 79.18 to 64.01. The February rating of 64.01 qualifies as "fair" which implies that, though it is not ideal, it is fairly safe. The site that was most affected was B. Its rating dropped from 74.94-a relatively low rating when considered sites A and C-to 57.43, the lowest recorded value across sampling events. Site C, by contrast, had the smallest difference in water quality, though it still decreased. The rating fell from 79.16 to 71.21. Since the second rating is above 70, it qualifies as "good", meaning that road salting had little impact on the overall rating of site $\mathrm{C}$. Through these sampling events, it is evident that the closer a site is to a main road, the more impactful road salt will be on overall water quality. The minimal impact on site $\mathrm{C}$ reveals that as the stream runs downward, some of the contaminants introduced by road salt dissipate into the water. This is reasonably supported because sites $\mathrm{A}$ and $\mathrm{C}$ were extremely similar in water quality prior to road salting; however, there was a large difference between ratings after road-salting took place.

\section{Limitations}

A drawback to the findings of this investigation is the small scale in which it was operated under. Though each site was carefully selected for its equidistance, the use of only three sites hinders the conclusions that can be drawn from this experiment. Another limitation of this study is that the full effect of salt could not be isolated from other contaminants. Since the melted snow was the medium in which the salt reached the water, preexisting contaminants in the snow could not be separated. By including the salt content test, this was somewhat accounted for, as an increase in salt was indeed evident. However, contaminants could influence the data for the other parameters tested as well. A biological survey of the organisms in the water could also prove effective in supporting the findings of this study, however it could not be conducted due to the limited resources of the study.

\section{Conclusion}

In reference to the impact on the Detroit river and the Clinton River Watershed as a whole, the Gibson Creek itself is negligible. However, when many streams, much like the Gibson Creek, are considered, the impact becomes significant. As seen through site C, contaminants do not remain in the water for long, but if many of the Detroit River's tributaries have contaminant points before they reach it, they will likely bring them into the river and affect its water quality. Since the city of Detroit uses the river for potable water, it is constantly being tested. However, in light of the Flint River Water Crisis, we as citizens cannot fully rely on governmental assurance of our safety. If, by any means, 
the use of road salt can be minimalized in cities around the metro-Detroit area, the contaminants that reach the water supply will be inconsequential. This change in road maintenance procedures can start as a municipal initiative and evolve into a state-wide regulation or movement to protect Michigan's waters and wildlife. Reduced road salt would not only benefit Michigan's water networks, it would also result in a safer driving environment for Michigan drivers, due to less road corrosion and fewer deer-related accidents.

\section{Future directions}

The experiments conducted showed that road salting events had a significant impact on the water quality of tested sites. Moreover, proximity to major roads also seemed to be a factor in the severity of the impacted streams. It would be advised for future research to be conducted on a larger scale in the Clinton River Watershed. This entails more test sites along the Gibson Creek, as well as other small creeks around the metro-Detroit area. More testing dates would also produce more reliable data. Future research could also explore the occurrence of this in other states and establish a link between climate and the prevalence of road salt contamination. At this juncture, it would be advised for the Michigan Department of Winter Maintenance to reduce its usage of salts in road deicing methods. Another viable recommendation encompasses an alternate use of salts, which would also prove to be a worthwhile investment. Research on different road salts used would produce a cost-benefit analysis that could shape public policy. Certain salts, though more expensive than $\mathrm{NaCl}$, consist of less toxic ions when dissociated. However, if the reduction in volume of salt used offsets the cost of new salts without compromising the deicing efficiency, Michigan could benefit from a reduction in salinization and environmental pollution.

\section{References}

1. Brisbois MC, Jamieson RC, Gordon RC, Stratton GC, Madani AC. Stream ecosystem health in rural mixed land-use watersheds. Journal of Environmental Engineering and Science. 2008 [accessed $2020 \mathrm{Apr}$ 30];7(5):439-452. doi:10.1139/s08-016

2. Coles JF, Cuffney TF, Mcmahon G, Rosiu CJ. Judging a brook by its cover: The relation between ecological condition of a stream and urban land cover in New England. NE Naturalist. 2010 [accessed 2020 Apr 30];17(1):29-48. doi:10.1656/045.017.0103

3. Cornwell M. Michigan Road salt: What is it costing us? Mackinac Center for Public Policy. 2011 Jun 7 [accessed 2020 Apr 30]. https://www.mackinac.org/15189

4. Corsi SR, Graczyk DJ, Geis SW, Booth NL, Richards KD. A fresh look at road salt: Aquatic toxicity and waterquality impacts on local, regional, and national scales. Environmental Science \& Technology. 2010 [accessed 2020 Apr 30];44(19):7376-7382. doi:10.1021/es101333u

5. Exall K, Rochfort Q, Marsalek J. Measurement of Cyanide in urban snowmelt and runoff. Water Quality Research Journal of Canada. 2011 [accessed 2020 Apr 30];4(2):137-141. https://www.researchgate.net/publication/274679009_Measurement_of_cyanide_in_urba n_snowmelt_and_runoff. doi:10.2166/wqrjc.2011.022

6. Fazio CA. Environmental impact of road salt and deicers [Press Release]: Carter Ledyard \& Milburn LLP. 2011 Feb 24 [accessed 2020 Apr 30]. https://www.clm.com/publication. cfm?ID=321 
7. Goel P, Saxena A, Singh DS, Verma D. Impact of rapid urbanization on water quality index in groundwater fed Gomati River, Lucknow, India. Current Science. 2018 [accessed 2020 Apr 30];114(03):650-655. doi:10.18520/cs/v114/i03/650-654

8. Gopalakrishnan S. A public health perspective of road traffic accidents. Journal of family medicine and primary care. 2012 Dec 1 [accessed 2020 Apr 30]. https://www.ncbi.nlm.ni h.gov/pmc/articles/PMC3893966/

9. Hersha DK, Wilson RS, Baird AM. What individuals know, do not know, and need to know about watershed health in an urbanizing USA Midwestern city: A mental model approach. Urban Water Journal. 2014 [accessed 2020 Apr 30];11(6):482-496. doi:10.1080/1573062x.2014.881891

10. Lerner KL, Lerner BW. Water pollution. The Gale Encyclopedia of Sciences. 2017 [accessed 2020 Apr 30]; 5:82-87. https://link.gale.com/apps/doc/CV2644032384/SCIC?u =troy35817\&sid=SCIC\&xid=acf251f3

11. Luo P, Kang S, Apip, Zhou M, Lyu J, Aisyah S, Binaya M, Regmi RK, Nover D. Water quality trend assessment in Jakarta: A rapidly growing Asian megacity. Plos One. 2019 [accessed 2020 Apr 30];14(7);1-17. doi:10.1371/journal.pone.0219009

12. Metre PCV, Waite IR, Qi S, Mahler B, Terando A, Wieczorek M, Meador M, Bradley P, Journey C, Schmidt T, et al. Projected urban growth in the southeastern USA puts small streams at risk. PlosOne. 2019 [accessed 2020 Apr 30];14(10):1-17. doi:10.1371/journal. pone.0222714

13. Mitchell MK, Stapp WB, Bixby K. Field manual for water quality monitoring: An environmental education program for schools. Dubuque, IA: Kendall/Hunt Pub. Co.; 2000. [accessed 2020 Apr 30]

14. NHD indexed locations for Water Quality Standards Index (WQSI). EPA. 2006 Jan 25 [accessed 2020 Apr 30 ]. https://cfpub.epa.gov/si/si_public_record_report.cfm?Lab=ORD \&TIM-

SType $=\&$ count $=10000 \&$ dirEntryId $=147201 \&$ searchAll $=\&$ showCriteria $=2 \&$ simpleSearch $=0 \&$ startIndex $=40001$

15. Oakland County. Michigan Motor Vehicle-Deer Involved Crashes. Michigan Government Traffic Crash Statistics. 2018 [accessed 2020 Apr 30]. http://publications.michigantraffic crashfacts.org/2018/Deer.pdf

16. Pecher WT, Madadha MEA, Dassarma P, Ekulona F, Schott EJ, Crowe K, Gut BS, Dassarma S. Effects of road salt on microbial communities: Halophiles as biomarkers of road salt pollution. PlosOne. 2019 [accessed 2020 Apr 30];14(9). doi:10.1371/journal.pon e.0221355

17. Sandru CM, Iordache MI, Radelescu AE, Zgavarogea R, Ionete R. Distribution of heavy metals in water and sediments from leaks of the Olt Watershed. Progress of Cryogenics and Isotopes Separation. 2019 [accessed 2020 Apr 30];22(1):77-91. http://search.ebscoh ost.com/login.aspx?direct $=$ true $\& \mathrm{db}=\mathrm{a} 9 \mathrm{~h} \& \mathrm{AN}=136759612 \&$ site $=$ ehost-live

18. Shortle J. Policy reforms needed for better water quality and lower pollution control costs Agricultural \& Applied Economics Association. 2017 [accessed 2020 Apr. 30] ;34(2):1-5. http://search.ebscohost.com/login.aspx?direct=true \&db=mat\&AN=13124 7178 
19. Shrivastava P, Kumar R. Soil salinity: A serious environmental issue and plant growth promoting bacteria as one of the tools for its alleviation. Saudi Journal of Biological Sciences. 2015 Mar 22 [accessed 2020 Apr 30]. https://www.ncbi.nlm.nih.gov/pmc/articl es/PMC4336437/

20. Viadero RC, Fortney RH. Water-Quality assessment and environmental impact minimization for highway construction in a mining-impacted watershed: The Beaver Creek Drainage. Southeastern Naturalist. 2015 [accessed 2020 Apr 30];14(7):112-120. doi:10.1656/058.014.sp712

21. Wilhelm JF, Bain DJ, Green MB, Bush KF, Mcdowell WH. Trace metals in Northern New England streams: Evaluating the role of road salt across broad spatial scales with synoptic snapshots. PlosOne. 2019 [accessed 2020 Apr 30];14(2). doi:10.1371/journal.po ne.0212011

22. Winter JG, Dillon PJ, Paterson C, Reid RA, Somers KM. Impacts of golf course construction and operation on headwater streams: Bioassessment using benthic algae. Canadian Journal of Botany. 2003 [accessed 2020 Apr 30];81(8):848-858. doi:10.1139/b03-081

23. Wurts W. Why can some fish live in freshwater, some in salt water, and some in both? World Aquaculture. 1998 [accessed 2020 Apr 30];29(1):65-87. https://www.research gate.net/publication/306960792_Why_can_some_fish_live_in_freshwater_some_in_salt_water_and_some_in_both/citation/download

24. Zeng W, Yue R, Zou Y, Xie J, Luo X. Analysis of the sources of water pollution in construction area of expressway around Shaoqing reservoir. IOP Conference Series: Earth and Environmental Science. 2018 [accessed 2020 Apr 30];170(032067). doi:10.1088/175 5-1315/170/3/032067. 